\title{
Spanish Migrating Newspapers: News Broadcast or Opinion Generators
}

\author{
Noemi Muñoz-Agustin1, Angel Vicario-Merino ${ }^{2 *}$ \\ ${ }^{1}$ International Cooperation Department, Spanish Red Cross, Madrid, Spain \\ ${ }^{2}$ Faculty of Education and Health, Camilo José Cela University, Madrid, Spain \\ Email: noemi@cruzroja.es, ^avicario@ucjc.edu
}

How to cite this paper: Muñoz-Agustin, N., \& Vicario-Merino, A. (2020). Spanish Migrating Newspapers: News Broadcast or Opinion Generators. Open Journal of Political Science, 10, 363-382.

https://doi.org/10.4236/ojps.2020.103023

Received: March 31, 2020

Accepted: June 2, 2020

Published: June 5, 2020

Copyright $\odot 2020$ by author(s) and Scientific Research Publishing Inc. This work is licensed under the Creative Commons Attribution International License (CC BY 4.0).

http://creativecommons.org/licenses/by/4.0/ (c) (i) Open Access

\begin{abstract}
The movement of populations is something that has been happening throughout history and is currently a key element in all the political agendas. The impact that the media has on the general opinion of society is undoubtable. With the systematic review of the headlines of four key Spanish Newspapers during the period of 2007-2012, we were looking for the tendencies and differences of 5 key newspapers concerning the same event at the same time. The following keywords in Spanish (Dugout, Sub Saharan, Moroccan, Avalanche, Massive arrival, Refugees, Alien law, Internment centers, Human trafficking, Trafficking) have been searched for in a Spanish newspaper repository. The results have been confronted between the newspapers, obtaining clear differences on the importance and the usage of the language repetition of terms to become opinion generators depending on the political moment of the country and the editorial line of the media.
\end{abstract}

\section{Keywords}

Immigrants, Africa, Newspapers, Media

\section{Introduction}

\subsection{Political Agenda}

Migration is currently one of the key elements of the policy agendas in either sides of the Atlantic. The importance in the US agenda comes from the migration waves coming from central and South America and in the case of Europe because of the arrival of migrants fleeing from the Syrian conflict or the African immigration. This movement of population comes with great stress to the destination areas as they have, according to international migration laws, the legal obligation to study the cases where the migrant is demanding asylum and de- 
termine whether he/she is eligible. This would provide the person with certain benefits in the arrival country, which will have an influence, amongst other places, the national budget and the areas where they will be welcomed. The traditional way is from their home country to a theoretical "safe haven" or "dorado" in a developed country, where all their problems will be solved, and the community services will provide them with the necessary security and basic services so as to have a calm life.

The increase in the migratory fluxes has had diverse control initiatives from the governments involved so as to reduce it or stop it. Examples of these measures have been:

- National Legal measures: modification of the national laws so as to accept, welcome or reject in a quick manner, the migrants that have arrived and are already in national soil.

- National Physical measures: creation and improvement of the already existing physical walls that separate one country with another. Examples of this can be found in either the U.S. with Mexico or in Europe, the fences between Spain and Morocco.

- Increased presence of security forces: The presence of members of different areas of national defense (police, military ...) has been increased, justifying it as dissuasive. The theory behind this presence is to discourage the migrants to go that way.

- Support to the midway countries: This type of support aims to support the countries through which the migrants are crossing, so as to provide the resources to avoid their crossing or to encourage them to stay there. Examples of these activities can be found in the E.U. supporting Turkey to create transition camps for the Syrian migrants or Spain with Morocco to reduce the flux of African migrants through the strait of Gibraltar.

The steps taken have been followed by its corresponding media coverage, analyzing and describing these initiatives according to the party in the government, the editorial line of the newspaper, providing the general public different ideas and news about the exact same situation.

\subsection{Spanish Situation}

Spain has, traditionally, been receiving immigrants from Africa through the Gibraltar straight as it is the shortest sea route from Africa to Europe. For years, rafts or dugouts (or "pateras" as they are designated in Spain) have been crossing the $14 \mathrm{~km}$ with people, some running away from the conflicts in their countries or others simply looking for a better life and more opportunities in Europe. Despite the feeling of the Spanish population, migration from África is more intra-regional or intra-continental rather than extra-continental, leaving these internal migrants in different countries within their continent. These migrant fluxes are nothing new, they have been occurring since there are records of African populations (REFERENCIA) and is one of the elements that makes Africa what it is. As Beatriz Alvear remarks (Alvear Trenor, 2008), there is an 
important element missing; real, believable, figures and data. There is not even a consensus on the African migrant population. According to the UN it is estimated that around 50 million people are African. The International Labor Organization estimates the African population in 20 million.

\subsection{African Movements}

One of the problems to analyze the phenomenon is the inaccuracy of data as Beatriz Alvear indicates in working document No. 50/2008 of the Elcano Royal Institute "There does not even seem to be agreement on the current amount of African migrant population 7 Since the UA states that of the 190 million migrants that the UN estimates exist in the international community, 50 million are Africans. For its part, the World Labor Organization figures them at 20 million (ILO, 2003), while the International Organization for Migration estimates that they are 16.2 million (IOM, 2003). To all this we must add the total absence of data on the population that crosses the African borders and the poor control of refugee flows; it is believed that almost 2.5 million of the 11 million world refugees live in Africa". What is known with certainty is that the majority of migratory flows occur from country to city. Rural areas are increasingly fragile and agricultural-livestock means are increasingly scarce for various reasons (climate change, absence of pastoral routes, lack of government support ...) and there is no other way of employability, so City is the forced solution. These people do it by running away from hunger and droughts with very few resources and opportunities, because what "jumping" to another continent becomes really difficult. If in the end it is done, it would be the minimum percentage that has had fortune in the city and has allowed them to save an indispensable minimum. It is a fact that supports the World Bank, who also adds, that extra-continental migrants also have a training background that does not have a majority of African population.

Another relevant data, which supports the intra-continental theory, is the existence of forced population movements as one of the causes that causes a greater number of people, linked to conflicts and violence, that cause millions of refugees, as is the case in the region of the great lakes or the horn of Africa. If we do an analysis of regions, we find West Africa and Sahel, East Africa and South Africa. In West Africa in 2006 according to the Ministry of Foreign Affairs of the French Government, $90 \%$ of the migrations occurred between regions, leaving only $10 \%$ to migrate to Europe, it is a very significant fact since it considers the "trampoline" of Africa and that there are $44 \%$ of African migrants. The scenario of East Africa is different and marked by conflicts and forced movements. For the most part we are not talking about immigrants but refugees, and the host countries (by border proximity) are Tanzania, Kenya and Uganda. As Beatriz Alvear points out in her report "According to data from the UN High Commissioner for Refugee Assistance (UNHCR) in Africa, 2,271,200 refugees were registered in 2007, of which 1,915,200 come from East Africa and Central Africa, specifically of the Horn of Africa (815.200) and the Great Lakes region $(1,100,000)$." And finally in South Africa, we find South Africa and Namibia as 
countries of destination and Mozambique, Malawi, Lesotho and Zimbabwe, as countries that emit emigrants. Migratory movements are long and phased processes, which can take months and years since during the "crossing" countries and personal situations change. Some of the countries that are crossed, are highly volatile or with chronic and intermittent conflicts, the laws on immigration matters are also varied, and in addition there is also an individual part. Each person's own resources, since many of them do not leave their country with all the economic amount necessary to reach Europe but have to make "stops" and work at different points of the trip, to earn enough money to Help get to the next point as seen in Figure 1. Migrants from West Africa have two fundamental transit routes, the central route (through Libya) or the western route (through Morocco). Three other important and historical nuclei of the migratory routes are Nigeria (Kano), Mali (Gao) and Algeria (Tamanrasset) and in a more recent era the "cayucos and pateras" that leave from Morocco, Mauritania and Senegal appear.

Since the 90s, Morocco has established itself in a country of emigration and immigration, but not because it is a country with legislation favorable to immigration policy, as many people think, since all African countries are obliged to

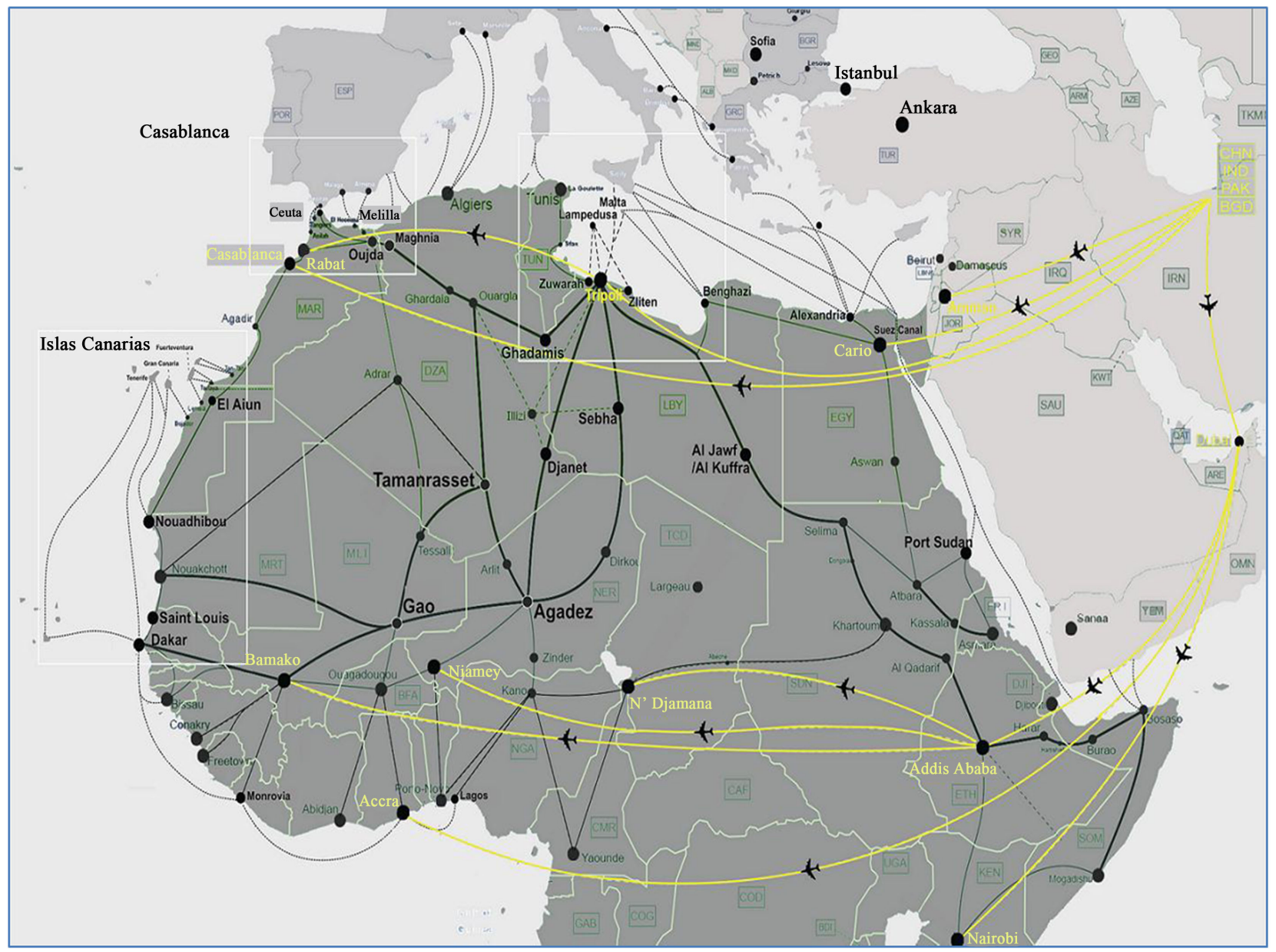

Figure 1. Mediterranean and African irregular migration itineraries. Source: (Cebrián \& Charef, 2012). 
have an entry visa to the country with the exception of eight (Côte d'Ivoire, Congo-Brazzaville, Guinea Conakry, Libya, Mali, Niger, Senegal and Tunisia) nor for the official flexibility of their borders since with the Sahara conflict the roads land between Mauritania and Algeria are closed. Although it is also estimated that almost all irregular migrants, who have been arrested or rejected by the Moroccan police have entered through the border with Algeria (see Figure 2), although this has been closed for years. To reach the Algerian-Moroccan border, migrant groups must cross about $1500 \mathrm{~km}$ of desert until they reach Oujda, a road full of challenges (sandstorms, dehydration, fevers, attacks ...).

In this way we can conclude that the sea route to the Canary Islands, at no time is it the "massive" or "easy" route of arrival of migrants, but on the contrary, extremely dangerous and that it represents a low percentage of African movements. This flux of immigrants has developed the academic studies so as to look for explanations since 1980, although it was not until 1990 with the increased amount of presence in the press that the academic manuscripts increased significantly. Studies such as the one developed by Kressova on the Migrants from Eastern Europe and its presence in the Spanish press (Kressova et al., 2011) have been used to focus and frame the study.

\subsection{A Little History}

The theoretical bases selected as pillars of this study are focused on public opinion. With them we share the importance of public opinion in social development but also how volatile and sensitive it can be to the media. We believe that a transformation of public opinion into a critical opinion could lead to a social transformation. So our first step, therefore, is to know what public opinion is, a quasi-virtual term and that has been defined in many and varied ways according

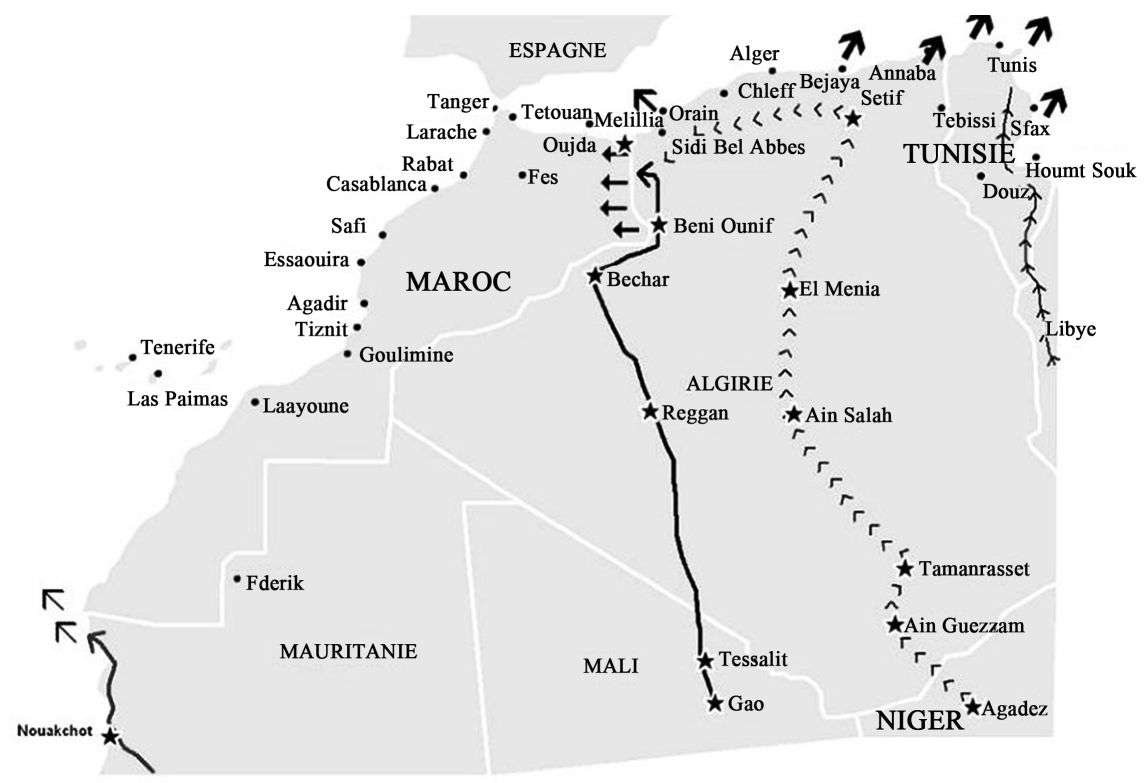

Figure 2. Illegal migration itinerary towards Morocco. Source: (Cebrián \& Charef, 2012). 
to the perspective followed; Of all of them, we have selected two that, because of their sociological perspective, we consider the most approximate for this study:

- Walter Lippmann from a mental-stereotyped perspective defines it as "the images that are inside our heads (...) of human beings, the images of themselves, of others, of their needs, purposes and relationships, are your public opinions" (Lippmann, 2017).

- Elisabeth Noelle-Neumann starts from a more psychosocial perspective and gives it a more open connotation, defining it as "opinions on controversial issues that can be expressed in public without isolating oneself" (Noelle-Neumann, 1974).

There are also divergent theories from those that reduce it to a simple set of individual opinions, to those that define it as the opinion of the majority, others believe they are the beliefs of the power groups and there is even a perspective that indicates that the opinion Public does not exist. Without having a consensus on what it is and how it is formed, in what there is a consensus is that public opinion exists in a context of mass communication and mass media. Walter Lippmann, in his work "Public Opinion" gives the media a more important position than just an influential actor; for Lippmann, the media create images of reality without being real, in other words, the media builds a parallel reality and society responds to them, this response would be public opinion.

Jose María Rubio summarizes the elements of public opinion in the following words (Rubio Ferreres, 2009): "The basis of public opinion is more cognitive than rational. On the one hand it is a consequence of representations, mental schemes, symbolic images that individuals construct in terms of reality. But on the other hand, these cognitive schemes, as sources of opinions, are mostly a partial representation. And finally, the family environment and shared by all individuals, let's call it 'world of life' s replaced by a 'pseudo-environment', to which political propaganda, media, individual images, self-centeredness and manipulation contribute, as well as the experience of worlds and realities not directly available." One of the most defining adjectives of today's society (especially the western one) is that it is a mediatic society. We have in our homes the "big window to the world", the television that is directing our focus to one direction or another, defining our world (both daily and distant). The most used tools to guide the "eye" of the viewer, are the news. These messages transmitted as truthful and objective information are actually those that mark the current situation and indicate what is news, when something is news and when it is not. The theory that has deepened more in this area is the theory of the agenda setting, which highlights how the media marks the agenda of the day's news and which in turn also indicates the context and limits of interpretation of reality, being its main objective to influence public opinion; as Jose María Rubio indicates in his article "the media agenda becomes the public agenda. In other words, the most prominent issues of concern become more important issues of concern" (Rubio Ferreres, 2009). This leads us to the concept that public opinion is the result of social influence and the media within a democratic context but then, what is its 
power?

As Miguel Angel Medina Muñoz indicates: Under optimal conditions of culture, interest and plurality we can, without a doubt, consider that the public becomes a true subject of opinion and as such will constitute a social power by itself; otherwise, the public will obviously continue to be social power, although the effective power of the public will have to be attributed to the informational companies (Muñoz, 1974). Within the Theory of the agenda setting or setting the agenda, we can define the public agenda as "the list of issues that the public considers important", while that the agenda of the media can be defined as "the list of issues with media coverage" and the political agenda "Lists of issues that politicians consider important." Through this theory it is intended to demonstrate the trends and patterns of coverage of the news and its influence on public perception, on what are the important issues of the day. Trying to contrast the relationship between the issues that stand out in the media with public opinion (measured through audiences or surveys); "This has the purpose of delimiting the impact of the media on the construction of images, on what is relevant in the public sphere". Another of the pillar theories in shaping public opinion and that is relevant in our study is Niklas Luhmann's Theming Theory. Theming theory is understood as "the process of definition, establishment and public debate of the great political issues determined by the media" (Luhmann, 2013). The cornerstone of this theory is to demonstrate that from the journalistic treatment of news on political issues, debates are generated that influence public education that result in opinions. The theory aims to show the link between the work of media communication and its impact on the processes of political communication in today's societies.

As José Ramón Santillán indicates, the political issues and the thematization process, two theoretical axes of the present work, can be explained from the journalistic treatment that the means for selection follow and debate of public issues, as well as the formation of political opinion in modern societies. In some ways, journalistic discourse is a space for the expression and negotiation of political conflicts between different social actors. The analysis of the thematization in the written press proposes to study the formation of currents of opinion on a political issue and determine its function of political communication in today's society (Santillán, 2007). One of the most revealing articles was that of Antolin Granados, (Kressova et al., 2010) where he makes an interesting journey on the relationship of the press and immigrants, that part of his thesis. The first thing that comes up is the small differences in the image given by the media of immigrants in the years 1998 with respect to 2006, as opposed to the great social changes that occurred in this area and in that period of time. In his thesis, Antolín Granados investigates the articles of ABC, El País, Diario 16 and El mundo during the years 1985-1992, concluding with the following ideas (Granados, 1998):

1) The administrative situation of immigrants makes the difference in profiles between immigrants. 
2) There is an important and non-proportional volume of news of immigrants of African origin, compared to the rest.

3) In the headlines of the news related to the subject, they quantify without relating to other figures, giving a feeling of invasion and massive and unattainable arrival by the receiving country.

4) With regard to the reception, it is true that the newspapers echo the violent acts towards the immigrant people but mentioning that they are isolated actions and of specific groups. On the other hand, there is a large number of news in the four newspapers about the feelings of solidarity and the work of NGOs for the integration of the newcomer.

5) Also highlight, for a small presence, related news about the life of immigrants (where they live, what they work for ...). Without this information, we still don't know the newcomer, being forever unknown.

In 2006, Antolín Granados revisits the presence of immigrants in the written press, from June 1 to September 30, 2006. Extracting three basic ideas:

1) $37.8 \%$ of the total information is focused on the arrival of the boats. Influencing the perception of immigration as a massive phenomenon and, consequently, its control measures (immigration laws, detention center, flow regulation ...).

2) Articles that link immigrants with criminal acts are relevant, not so much for the number of them but for their form of writing, giving more importance to who has done it than what has been done and its consequences, presenting the immigrant as a threat.

3) Information on integration and coexistence, remain scarce. And when they appear, they link the immigrant to poverty and marginalization. Influencing exclusion as a decision and flying isolated cases as a symbol of radicality and intransigence with the habits and customs of the host society. The "report on information treatment of immigration 2007" made by the Department of Audiovisual Communication and Advertising, Migration and Communication Observatory (MIGRACOM) manages a sample of 455 news programs of state-of-the-art television and radio networks and the written press sample consists of the following newspapers: El País, ABC, El Mundo, El Correo Español, El Diario Vasco, La Vanguardia, El Periódico de Catalunya, La Voz de Galicia, Faro de Vigo, Levante Mercantil, Sur, Ideal Granada and Las Provincias and as a free press Que !, 20 minutes, ADN and Metro.

The comparison it makes about the time the media devotes to immigration issues with respect to the total information panel is key, as it makes a division of five levels of information: national politics, international politics, economics, society and sports; In national politics is where immigration linked to the different positions of political parties, arrivals and control measures and regularization processes gain more weight. Within the international policy "they are news of debates and agreements at European level in the matter of immigration, caused in large part, by the continuous arrival of immigrants". In the economic bloc, immigration is related to employment and consumption and finally in the so- 
ciety section, they are news where immigrants are involved or as victims or criminals. The report, analyzes an sample of 543 headlines highlighted in 2007 (selected by preferred informative criteria such as the space occupied in columns and the most important place allocated on the page) the following denominations appear in the headlines: Africans (africanos), Algerians (Argelinos), Illegals (ilegales), Immigrants (inmigantes), cast away (náufragos), undocumented (indocumentados), sub-Saharan (sub-saharaiano) and "other denominations" (otrasdenominaciones). When analyzing the subject of the newspapers headlines, immigrants appear as main characters in the following categories:

1) Aggressors, assaulted, alleged criminals $3.4 \%$.

2) Deceased 2.3\%.

3) Those who arrive $47.7 \%$.

4) Those who claim/think/report $10.5 \%$.

5) Those who face "paperwork", regularization and certain personal obstacles $9.3 \%$.

6) Those who integrate $5.8 \%$.

7) Workers and entrepreneurs $15.2 \%$.

8) Other 5.8\%.

The National Statistics Institute makes the following distinction by nationalities:

- African Continent: Algeria, Gambia, Ghana, Guinea, Equatorial Guinea, Morocco, Mauritania, Nigeria, Senegal and other African countries that are grouped in an unidentified heading.

- South America: Argentina, Bolivia, Brazil, Colombia, Chile, Ecuador, Paraguay, Peru, Uruguay, Venezuela and other countries in South America.

- European Union countries: Belgium, Bulgaria, Denmark, Spain, Finland, France, Ireland, Italy, the Netherlands, Poland, Portugal, United Kingdom, Germany, Romania, Sweden, Lithuania and other countries of the European Union.

- Rest of Europe: Norway, Switzerland, Ukraine, Moldova, Russia and other countries in the rest of Europe.

- Asia: Bangladesh, China, the Philippines, India, Pakistan and other countries in Asia.

- Central America and the Caribbean: Cuba, Honduras, Nicaragua, Dominican Republic and other countries of Central America and Countries.

- North America: United States and Mexico.

Viewing the global data, the migratory weight is concentrated in three geographical areas and in this order: 1) Countries of the European Union, 2) South America and 3) Africa.

During this period of time the census did not require the need for work or residence authorization, it was sufficient the passport or identification document of your country to be collected in it. Therefore, although we know that many immigrant people were not registered, it is not an analysis of people with residence and/or work permits, therefore we use it to make the comparison between 
nationalities. If we look at the years 2008 and 2009, which were the most striking years of arrivals of African immigrants by sea, they are still far from the countries of the European Union and South America as seen in Table 1.

If to belittle that the African immigration was striking, perhaps not so much for the global figures but for the rapid rise, we can verify that it was very far from the first position, however in the media coverage it was very wide and its impact on the headlines, as we have been able to check in the previous notable sections. In the following years the presence of African immigrants declines powerfully, reaching 40,766 people in 2012, less than half the same as the total immigration figures in Spain, probably because the economic crisis in Spain was reaching its point algid. But even so, while the term "cayuco" appears very residual, "patera" still has significant coverage for some newspapers; for example, in ABC there are 114 headlines with the word "patera" and in El País on 61 occasions. According to the Frontex general report and the study by S. P. Reikman (FRONTEX, 2008; Riekmann, 2016), detections by sea to the Spanish coast fell 70\% compared to 2006 , a total of 11,751 detections, however Italy had $13 \%$ more detections and Greece had a very striking rise with a $170 \%$ more than the previous year.

In this report, it is pointed out that the areas with the highest risk of entry of illegal immigrants, according to the detections that occurred, would be:

- Southern-Eastern European land border, especially the Greek-Albanian and Greek-Turkish border.

- Borders areas of North and West Europe, especially France.

- Maritime borders of the South and South. Eastern Europe, especially Greece-Turkey and Italian coasts.

As can be seen, the Spanish maritime border no longer appears with a high risk of illegal immigration entry, but in the newspapers, they still appear as a clear and future "threat". The member states of the European Union "returned" 130,000 immigrants to their countries of origin or transit, most of the returns were made at land or air borders. Poland was the country that most immigrants rejected, followed by France, Spain and the UK. In 2009, according to the Frontex General Report 2009 (FRONTEX, 2010), the number of arrivals to the Canary Islands fell much more, only 2280 of 9200 arrived that were intended to arrive since they were captured at the places of departure, due to the agreements between Mauritania and Senegal with the European Union. In 2012, the numbers of detections continue to fall, close to a quarter compared to 2011, the predominant nationalities were Algerian and "sub-Saharan" (does not identify

Table 1. Total number of immigrants in Spain according to origin (Source: National statistical institute).

\begin{tabular}{cccccc}
\hline & 2008 & 2009 & 2010 & 2011 & 2012 \\
\hline Countries of the European Union. & 200.067 & 151.595 & 158.378 & 164.290 & 131.885 \\
South America. & 175.909 & 91.842 & 66.834 & 63.763 & 47.412 \\
Africa & 111.405 & 70.444 & 50.255 & 47.848 & 40.766 \\
\hline
\end{tabular}


nationalities) leaving Morocco and Algeria. It also points out that together with Germany, Switzerland, Greece and France, Spain is one of the countries that detects the most irregular immigrants established in the country (Riekmann, 2016). In the 2007 Annual Report: on racism in the Spanish State of SOS Racism (SOS Racismo, 2007), it includes very revealing information: " $75 \%$ of immigrants entered the Spanish State through airports. According to data from the Unified Police Union, 55\% of immigrants who entered the Spanish State, in ten months in 2006, did so through Barajas Madrid Airport, while 20\% accessed through Prat Airport in Barcelona. Between 10\% and 15\% went through land borders and only $5 \%$ arrived in Spain by canoes from Africa".

\section{Methodology}

The study has been based on the analysis of keywords in the press headlines in a specific time period, considering the headlines the key element to attract attention of the reader. The selection of the newspapers to be analyzed has been based on their rates of most viewers and most paper copies sold plus one (La Vanguardia) as it is based on a very specific region of Spain with high levels of immigrants. Using this criterion, the Spanish National newspapers selected were: El País, ABC, El Mundo and la Vanguardia and the time period has been between 2007-2011, as these years have been active taking into consideration the arrival of immigrants. The timeframe was selected to be that of 2007-2011 so as to continue with the analysis of the study developed by Granados (Granados, 1998) between 1985-1992 and considering that during the period 1998-2006 was a small impact found in the immigration news in Spain.

The sample was obtained from the online news repository MUGAK based on news concerning migration movements. The search has been performed using key words which have been identified in the already described studies as strong and powerful in the sense of sending messages. Using the internal search engine of the webpage, each and every single term was searched for using the filters of year, newspaper and keyword, one by one, recording the results.

The inclusion criteria were: results obtained from the search using the year, newspaper and keyword. The exclusion criteria were to have the keyword more than once in the headline, in which case the headline was only counted once, not twice.

The key words in Spanish have been: Patera, Cayuco, Subsahariano, Magrebí, Avalancha, Llegada masiva, Refugiados, Ley de extranjería, Centros de internamiento, Trataamd Tráfico.

The key words translated to English have been: Dugout, Sub Saharan, Moroccan, Avalanche, Massive arrival, Refugees, Alien law, Internment centers, Human trafficking and Trafficking.

These keywords were selected as they have a high significance in the way they provide a type of image and feeling to the reader. The search was performed in Spanish. 


\section{Results}

The first thing we realize when we analyze the data is the difference in coverage of the different media; El País is at the head of the number of immigration-themed articles with a number of 8904 articles compared to 4258 of $\mathrm{ABC}$ and 5024 of El Mundo, all of national circulation, that is, more than $40 \%$ of the total articles analyzed (the results can be found in the Annex). This data gives us a very revealing a priori vision, since being the reality the same for all, as are the migratory movements, the media can enlarge or dwarf the social repercussion due to its editorial line or ideology.

In the same way, we see the progression of publication according to the years, with the years 2007 and 2008 being the ones with the most publications, coinciding with the increase in the migratory flow by sea to the Canary Islands from the African coasts. Although it is true, that it was a striking ascent of the use of this route, we will compare with the real figures of immigration in Spain. In these years, it is where the words "pateras" and "cayucos" predominate, which were used in 13\% of the headlines of the years 2007 and 2008, percentage made of the total of the newspapers. It is striking that it is also during those years that the term "avalanche" begins to be used especially by El País, which in 2008 uses it 112 times in its headlines.

The newspaper "El Pais" is the media with the most references of all the media analyzed, with a clear pattern where "patera" is clearly defined, in contraposition to "cayuco" which would be the similar term that could be used. See how the keyword "avalanche" was mainly used as shown in Figure 3. The full dataset can be found on Table A1 (Annex).

On the second position in number of headlines is "ElMundo" with a clear tendency over the years with the terms "trata" and "Patera" as seen in Figure 4. The 2009-star keywords for this media were "trata" and Cayuco". The full dataset can be found on Table A2 (Annex).

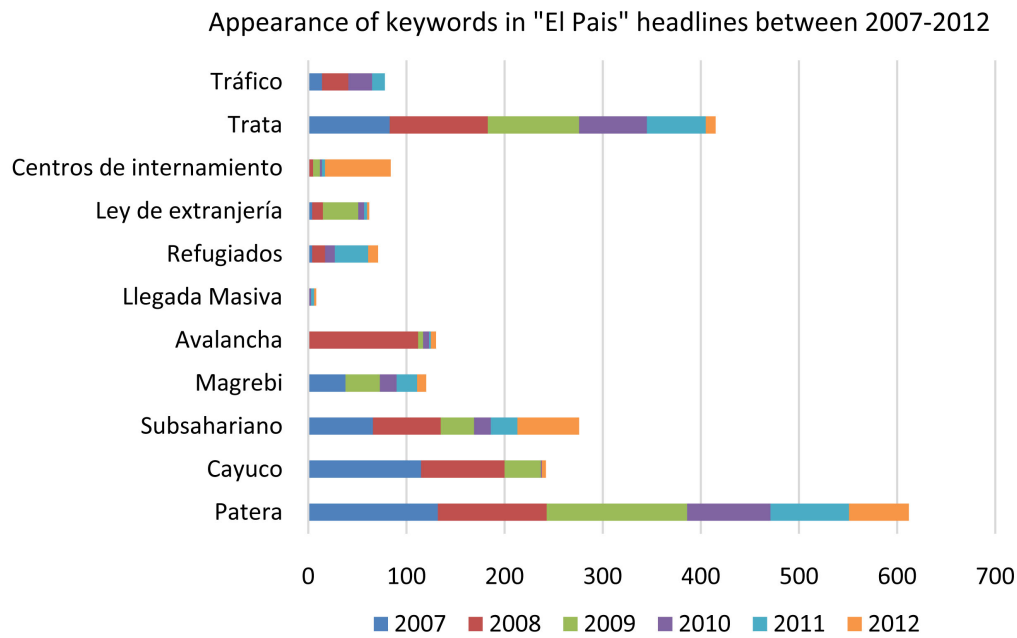

Figure 3. Appearance of keywords in "El Pais" headlines between 2007-2012. (Source: Results from the study.) 


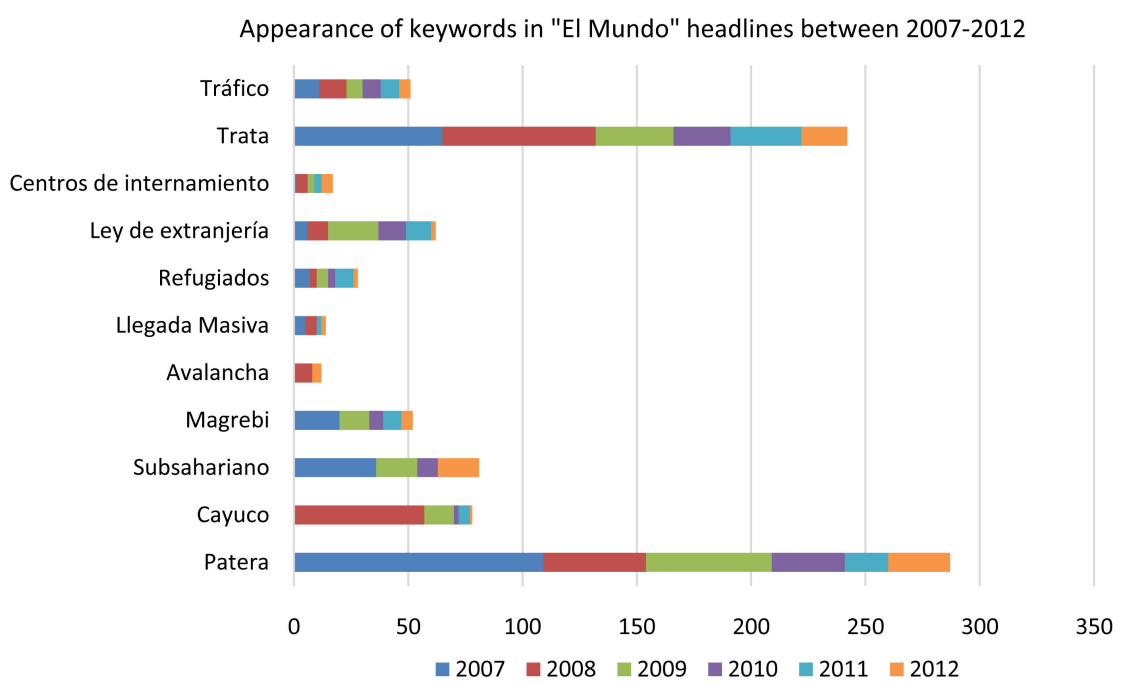

Figure 4. Appearance of keywords in "El Mundo" headlines between 2007-2012. Results from the study. (Source: Results from the study.)

"ABC" is the third newspapers with the most headlines concerning immigration. Significant is the amount of times that the term "cayuco" was used, in comparison to other media as seen in Figure 5. The full dataset can be found on Table A3 (Annex).

In last place, but also with a least share of readers is "La Vanguardia", where we can see how the headlines in 2007 are proportionally higher with the terms of "patera", "cayuco", Subsahariano", "Magrebí" and in a smaller amount "trata". Then in 2009 the key words go to "trata" and "Cayuco". This newspaper is mostly distributed in the arrival areas of the African immigrants, which can explain the high percentage of headlines in 2007 whereas the national newspapers (first 3) didn't give it that much presence in their headlines as seen in Figure 6. The full dataset can be found on Table A4 (Annex).

The graphs are not on scale on purpose to be able to visualize the differences in the terms, but the scales on each graph must be taken into consideration as we have a variation of under 120 accumulated appearances of keywords in newspapers such as "La Vanguardia" up to over 600 in "El País".

\section{Discussion}

Very related to the analyzed terms, "sub-Saharan" and "Maghreb" appear, which in the same way are concentrated between 2007 and 2008, in more than 4\% of the headlines studied in that time slot. According to the sub-Saharan SAR, it belongs to a part of Africa, which is located south of the Sahara and the term Maghreb is defined as a native of the Maghreb, part of northwestern Africa, which includes Morocco, Tunisia and Algeria. As we can see, they are extremely general terms, which group cultures, countries and identities of an entire continent in a single word, giving the feeling that all the people who arrive are equal, indistinct and making each one lose their individuality and of course forgetting the Causes or reasons to emigrate. 


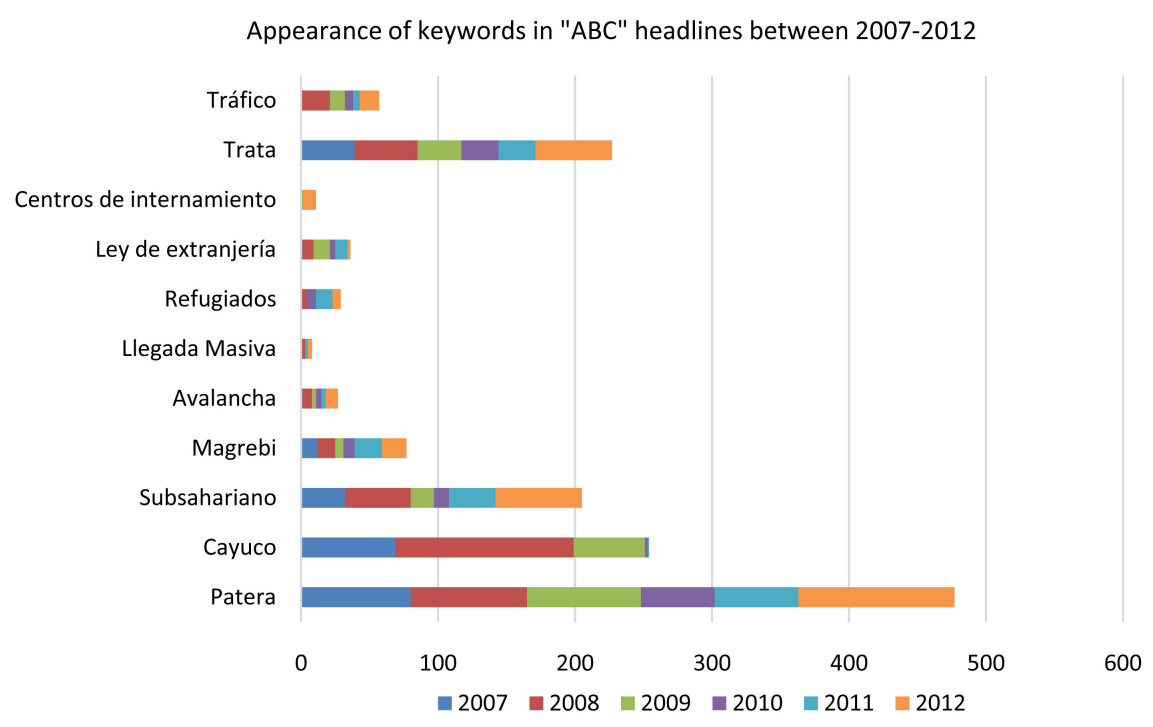

Figure 5. Appearance of keywords in "ABC" headlines between 2007-2012. Results from the study (Source: Results from the study).

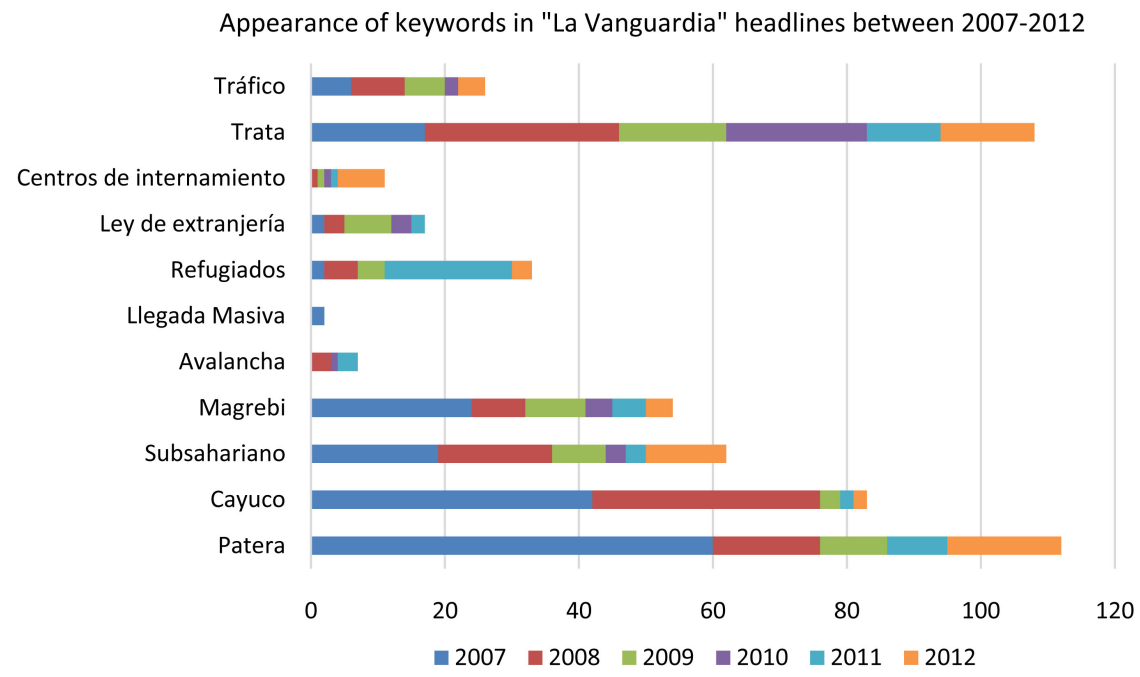

Figure 6. Appearance of keywords in "La Vanguardia" headlines between 2007-2012. Results from the study (Source: Results from the study).

In June 2007, Sara Prestianni, in the framework of the research promoted by the LIBE Committee (Committee on Civil Liberties, Justice and Internal Affairs of the European Parliament) on the "Conditions of citizens of third countries hosted in the centers (fields of detention, open centers and transit zones) attending in particular to the services available by people with specific needs, in the 25 States of the European Union", he managed to visit some Spanish CIES. Of these visits, he made two reports in which, when talking about the CIE of Fuerteventura he indicated that "the center is divided into two zones, on the one hand two large ships with a capacity for 350 people each, equipped with a bathroom and a shower and flooded with waste accumulated for days. On the other hand, very small cells, but equipped with about twenty berths each, line up one 
after the other. In the gloom, the faces of the migrants locked up approach the bars, all are dressed in the same way and tell the same tragic story of the sea crossing. They also tell us that they spend their days locked in the cells, and that they leave once a day, to eat."

In February 2010, the Spanish Association for International Human Rights Law filed a complaint with the United Nations Committee about the irregular operation of the detention centers for Foreigners in Spain, the Committee responded in March, pointing out its concern over the excess of the retention time of immigrants, the physical conditions within the CIES and the lack of access of the NGOs to these centers. It is striking to see the little impact they had in the written press, appearing only 12 times in the total of the newspapers analyzed in the 2007 and 2008 times, and in 2010 only three times (in El Country twice and once in La Vanguardia).

With regard to the Immigrants Law, the terms appear very residually during the years 2007-2008, and only has an increase in 2009, coinciding with the reform of the foreign law 2/2009 (Rey de España, 2009) carried out in that year, in the Later years it seems to be diluted, mentioning it so twice as per newspaper (except for the Vanguard that does not mention it on any occasion) during 2012.

When analyzing the terms "refugees, trafficking and trafficking" we can see that the word Refugees appears 161 times in the total of the newspapers in the interval of 2007-2012, that represents $0.75 \%$ of the total of the analyzed sample. It seems surprising the shortage of related news considering that during the years 2007-2008 many of the news were about the arrivals of African immigrants, continent with many countries in conflict or subjected to forced movements. We do not say that the emigrated people were asylum seekers but that they are not collected if they are or not. According to the 2009 CEAR report (CEAR, 2009), "in 2008, the number of asylum seekers in Spain was reduced by $41 \%$ ", a fact that makes us go back to 1989 , and that makes us understand the difficulties of accessing the asylum application In our country. In this year the Migrant Detection Center in Naodhibou in Mauritania is still in force and full activity, which is the center where all the emigrants expelled at the borders of Morocco arrive and direct from Spain. According to the CEAR report "In 2008, 355 people applied for asylum in the Canary Islands (...), those 355 people who demanded international protection represent only $3.87 \%$ of those who arrived by boat irregularly to the archipelago in 2008". In global figures, during 2008 asylum seekers fell $41 \%$ compared to 2007 , denying asylum to $94.66 \%$ of people who requested it.

Before entering the impact of the words "trafficking and trafficking" we will clarify them since they are different terms. As Professor Luis Mena (Martínez, 2010) indicates the basic differences between trafficking and trafficking are centered on consent (which does not exist in trafficking), exploitation (which does not exist in the traffic) and transnationality (which is not necessary in trafficking). We can consider trafficking as an importation of slaves, while traffic is an export of emigrants (Campana \& Varese, 2016). One of the major problems in 
addressing the issue of trafficking is the quantification of data, since there are no precise statistics. Another point is the assimilation of the term of trafficking with sexual exploitation, which although they are a large part of the cases identified, there is also trafficking for purposes of labor exploitation that remain invisible.

If we go to our data analysis, the first thing we observe is the difference in news related to this term according to the media. Although, El País is the newspaper that has more headlines related, it goes from having 100 in 2008, to 10 in 2012, while $A B C$ so has 46 headlines related to trafficking in 2008 and 56 in 2012. La Vanguardia and El Mundo also do not follow a similar line in years and numbers. We cannot relate the number of data detected since, for example, in 2007 we found 2521 cases, in 2009, 6157 were detected, in 2010 there were 15,075 people identified and 2011 they dropped to 14,370 (State Attorney General's Office). As indicated in the Ombudsman's report of 2011 (del Pueblo, 2012) during the years 2009 and 2010, the profile of people at risk cd being victims of trafficking for the purpose of sexual exploitation in Spain, she is a Romanian woman between 18 and 32 years old and a woman of Brazilian nationality between 33 and 42 years old. (...) 47\% of the victims come from America, 45\% from Europe and 7\% from Africa.

The study performed by C. Muñiz (Muriel et al., 2014) confirms the negative view that the Spanish press, not only the written, but also the TV has and expresses on the immigration situation in Spain. This study did find links between the positive news concerning the economic growth due to the immigrants and the negative news linked to the increase in vandalism and violence. It seems that the appearance of the topic in the media is random or dictated by editorial causes. Putting the focus on the subject individually without really being connected to the reality of the stage or keeping track of it.

\section{Conclusion}

Throughout the document, we have reviewed the weight of the media in Spain and described its impact on public opinion and the creation of stereotypes. We have revealed the easy fact that a new event, such as the increase in the use of sea lanes by African immigrants, can be "enlarged and enlarged" to become a threat when the actual data is not striking if we see it in a global scenario.

With the comparison between newspapers, we have verified how the same reality has a different weight, so according to the readers of each newspaper they will have their own version of reality. With the analysis of the use of words of the media with different ideologies and editorial lines, we have seen how the use of terminology such as "sub-Saharan" or "Maghreb" can be used despectively and be an opinion generator depending on the repetition. On the other hand, the words "refugee" or "detention center" are diluted or marginalized, that is, as rights barely appear on the cover, although there have been relevant events that had European repercussions for Spain.

In brief, when facing the same reality, the same time period and the same events as they are told by different media we have been able to clearly identify 
the way news migrate their editorial lines depending on the political party in charge and their interests.

\section{Conflicts of Interest}

The authors declare no conflicts of interest regarding the publication of this paper.

\section{References}

Alvear Trenor, B. (2008). Los flujos migratorios actuales en África Subsahariana: El pre dominio de la migración intra-africana sobre la extra-africana (Working Paper 50/2008, p. 21). Real Instituto Elcano.

Campana, P., \& Varese, F. (2016). Exploitation in Human Trafficking and Smuggling. European Journal on Criminal Policy and Research, 22, 89-105. https://doi.org/10.1007/s10610-015-9286-6

CEAR (2009). La situación de las personas refugiadas en España. Informe de 2009 (Vol. 1). https://cear.es/wp-content/uploads/2013/05/Informe-2009-de-CEAR.pdf

Cebrián, J. A., \& Charef, M. (2012). La inmigración irregular española procedente de Marruecos.

Del Pueblo, E. D. (2012). La trata de seres humanos en España: Víctimas invisibles. Defensor del Pueblo.

FRONTEX (2008). Frontex General Report 2007 (General No. 2007, p. 62). FRONTEX. https://frontex.europa.eu/assets/Key Documents/Annual report/2007/frontex general report 2007 final.pdf

FRONTEX (2010). Frontex General Report 2009 (General No. 2009, p. 58). FRONTEX. https://frontex.europa.eu/assets/Key Documents/Annual report/2009/gen rep 2009 en.pdf

Granados, A. (1998). La imagen del inmigrante extranjero en la prensa española: $A B C$, Diario 16, El Mundo y El País (1985-1992). Tesis Doctoral, Granada: Universidad de Granada.

Kressova, N., Fernándes Echevarría, J., \& García Castaño, F. J. (2011). Migrantes de Eu ropa del Este y su protagonismo en los medios de comunicación en España. http://dialnet.unirioja.es/servlet/oaiart?codigo $=4031668$

Kressova, N., Granados, M., Castaño, F. J. G., \& Granados, A. (2010). Poniendo adjetivos a la inmigración. Observaciones sobre la imagen del colectivo inmigrante proyectada desde la prensa andaluza. Mediterráneo Migrante: Tres Décadas de Flujos Migratorios (pp. 217-239).

Lippmann, W. (2017). Public Opinion. Abingdon-on-Thames: Routledge.

Luhmann, N. (2013). A Sociological Theory of Law. Abingdon-on-Thames: Routledge.

Martínez, L. M. (2010). Los números de la trata de personas en España. Documentación Social, 159, 151-168.

Muñoz, M. A. M. (1974). La opinión pública y el poder político. Revista de Estudios Políticos, 198, 193-212.

Muriel, C. M., Perosanz, J. J. I., Parra, J. A. O., \& Hernández, C. S. (2014). El tratamiento informativo de la inmigración en los medios españoles. Un estudio comparativo de la prensa y televisión. Perspectivas de La Comunicación, 1, 97-112.

Noelle-Neumann, E. (1974). The Spiral of Silence a Theory of Public Opinion. Journal of 
Communication, 24, 43-51. https://doi.org/10.1111/j.1460-2466.1974.tb00367.x

Rey de España (2009). Ley 12/2009, de 30 de Octubre, Reguladora del Derecho de Asilo y de La Protección Subsidiaria.

Riekmann, S. P. (2016). Security, Freedom and Accountability: Europol and Frontex. In Security versus Justice (pp. 35-50). Abingdon-on-Thames: Routledge.

Rubio Ferreres, J. M. (2009). Opinión pública y medios de comunicación. Teoría de la'agenda Setting.

Santillán, J. R. (2007). De la información a la opinión. Modelo para el análisis periodístico de los temas políticos. Revista Razón y Palabra, 12.

SOS Racismo (2007). Informe anual 2007: Sobre el racismo en el estado español. https://drive.google.com/file/d/0B3D3H-B1pez2M0pOc1BjS1M3M3M/view 


\section{Annex}

Table A1. Headlines of "El País" according to key words. (Source: Search results from www.mugak.com).

\begin{tabular}{ccccccc}
\hline Newspaper & \multicolumn{7}{c}{ El País } \\
\hline Year & 2007 & 2008 & 2009 & 2010 & 2011 & 2012 \\
\hline Total headlines & 1.775 & 1.876 & 1.518 & 1.707 & 1.068 & 960 \\
Patera & 132 & 111 & 143 & 85 & 80 & 61 \\
Cayuco & 115 & 85 & 37 & 1 & 0 & 4 \\
Subsahariano & 66 & 69 & 34 & 17 & 27 & 63 \\
Magrebi & 38 & 0 & 35 & 17 & 21 & 9 \\
Avalancha & 0 & 112 & 5 & 6 & 2 & 5 \\
LlegadaMasiva & 1 & 0 & 0 & 2 & 3 & 2 \\
Refugiados & 4 & 13 & 0 & 10 & 34 & 10 \\
Ley de extranjería & 4 & 11 & 36 & 6 & 3 & 2 \\
Centros de internamiento & 1 & 4 & 7 & 2 & 3 & 67 \\
Trata & 83 & 100 & 93 & 69 & 60 & 10 \\
Tráfico & 14 & 27 & 0 & 24 & 13 &
\end{tabular}

Table A2. Headlines of "El Mundo" according to key words. (Source: Search results from www.mugak.com).

\begin{tabular}{ccccccc}
\hline Newspaper & \multicolumn{5}{c}{ El Mundo } & \\
\hline Year & 2007 & 2008 & 2009 & 2010 & 2011 & 2012 \\
\hline Total headlines & 1.363 & 1.129 & 869 & 725 & 476 & 462 \\
Patera & 109 & 45 & 55 & 32 & 19 & 27 \\
Cayuco & 0 & 57 & 13 & 2 & 5 & 1 \\
Subsahariano & 36 & 0 & 18 & 9 & 0 & 18 \\
Magrebi & 20 & 0 & 13 & 6 & 8 & 5 \\
Avalancha & 0 & 8 & 0 & 0 & 0 & 4 \\
LlegadaMasiva & 5 & 5 & 0 & 0 & 2 & 2 \\
Refugiados & 7 & 3 & 5 & 3 & 8 & 2 \\
Ley de extranjería & 6 & 9 & 22 & 12 & 11 & 2 \\
Centros de internamiento & 1 & 5 & 3 & 0 & 3 & 5 \\
Trata & 65 & 67 & 34 & 25 & 31 & 20 \\
Tráfico & 11 & 12 & 7 & 8 & 8 & 5 \\
\hline
\end{tabular}

Table A3. Headlines of "ABC" according to key words. (Source: Search results from www.mugak.com).

\begin{tabular}{ccccccc}
\hline Newspaper & \multicolumn{7}{c}{ ABC } \\
\hline Year & 2007 & 2008 & 2009 & 2010 & 2011 & 2012 \\
\hline Total headlines & 775 & 1.124 & 725 & 461 & 475 & 698 \\
Patera & 80 & 85 & 83 & 54 & 61 & 114 \\
Cayuco & 69 & 130 & 52 & 2 & 1 & 0 \\
\hline
\end{tabular}




\section{Continued}

\begin{tabular}{ccccccc}
\hline Subsahariano & 32 & 48 & 17 & 11 & 34 & 63 \\
Magrebi & 12 & 13 & 6 & 8 & 20 & 18 \\
Avalancha & 1 & 7 & 3 & 4 & 3 & 9 \\
LlegadaMasiva & 0 & 3 & 0 & 0 & 2 & 3 \\
Refugiados & 0 & 4 & 0 & 7 & 12 & 6 \\
Ley de extranjería & 1 & 8 & 12 & 4 & 9 & 2 \\
Centros de internamiento & 0 & 0 & 2 & 0 & 0 & 9 \\
Trata & 39 & 46 & 32 & 27 & 27 & 56 \\
Tráfico & 0 & 21 & 11 & 6 & 5 & 14 \\
\hline
\end{tabular}

Table A4. Headlines of "La Vanguardia" according to key words. (Source: Search results from www.mugak.com).

\begin{tabular}{ccccccc}
\hline Newspaper & \multicolumn{7}{c}{ La Vanguardia } \\
\hline Year & 2007 & 2008 & 2009 & 2010 & 2011 & 2012 \\
\hline Total headlines & 637 & 636 & 453 & 713 & 463 & 357 \\
Patera & 60 & 16 & 10 & 0 & 9 & 17 \\
Cayuco & 42 & 34 & 3 & 0 & 2 & 2 \\
Subsahariano & 19 & 17 & 8 & 3 & 3 & 12 \\
Magrebi & 24 & 8 & 9 & 4 & 5 & 4 \\
Avalancha & 0 & 3 & 0 & 1 & 3 & 0 \\
LlegadaMasiva & 2 & 0 & 0 & 0 & 0 & 0 \\
Refugiados & 2 & 5 & 4 & 0 & 19 & 3 \\
Ley de extranjería & 2 & 3 & 7 & 3 & 2 & 0 \\
Centros de internamiento & 0 & 1 & 1 & 1 & 1 & 7 \\
Trata & 17 & 29 & 16 & 21 & 11 & 14 \\
Tráfico & 6 & 8 & 6 & 2 & 0 & 4 \\
\hline
\end{tabular}

